\title{
A Gothic-Renaissance Synthesis in a Diego de Riaño Vault
}

\author{
Antonio Ampliato ${ }^{1}$ (1) Eduardo Acosta ${ }^{1}$ (])
}

Published online: 5 December 2019

(c) Kim Williams Books, Turin 2019

\begin{abstract}
The aim of this article is to explain the design and construction processes employed in the ribbed vault prolonged by translation which Diego de Riaño (†1534) built in the antesacristy of the church of Santa María in Carmona. The vault represents an outstanding synthesis between the Late Gothic diagonal ribs and severies and the emerging systems that adopt the form of orthogonal grids and tend towards a unitary volumetric composition. The work reflects the coexistence of two different architectural languages in Andalucía in the first half of the sixteenth century, a transitional situation which, in our view, Riaño deliberately embraces in his design. Based upon rigorous photogrammetric mapping, this paper analyses the formal and geometric characteristics of this exceptional work. The analysis conducted reveals that this was not simply an experiment with form, because beneath their singular appearance the geometric designs point to the investigation of new solutions.
\end{abstract}

Keywords Diego de Riaño · Ribbed vault · Oval · Gothic $\cdot$ Renaissance

\section{The Crossroads in Spanish Architecture in the First Third of the Sixteenth Century}

Erwin Panofsky, in his book Renaissance and Renascences in Western Art (1960), examined in great detail the numerous irruptions of classical models that periodically emerged in Europe during the Middle Ages. However, the Italian Renaissance ushered in a radical novelty that marked a change of epoch in the sense that "the classical past began to be looked upon from a fixed distance, quite comparable to the 'distance between the eye and the object' in... focused perspective, [which permitted] a total and rationalised view" (Panofsky 1960: 166 and 173). This historical awareness of distance, like so many other cultural aspects at the beginning

Eduardo Acosta

eduacosta@us.es

Antonio Ampliato

alab@us.es

1 University of Seville School of Architecture, Seville, Spain

(virkhäuser 
of the Modern Era, brought with it a new abstract value and also, a brand new space never before seen and now claimed for creation. Undoubtedly, it is well worth for us exploring in any of its possible manifestations.

Compared with the forcefulness of the Italian process, the dynamics in other parts of Europe were very different. On the Iberian Peninsula the Gothic language had accompanied a long process of political and social reconstruction that aspired to unify all the peninsular kingdoms in the face of Islamic domination. Between the latter decades of the fifteenth century and the early sixteenth century, Iberian Late Gothic enjoyed moments of great brilliance, occasionally incorporating an interesting experimental component. At the beginning of the sixteenth century, in the recently constituted Kingdom of Spain, artistic manifestations combined traditional and new languages while architectural production was immersed in a complex combination of tendencies (Marías 1989). In any case, the drives for modernisation were anything but marginal. Many of the powerful figures in political and ecclesiastical circles were schooled in humanistic theory and promoted the use of Classic forms. The 1520s saw the publication of Medidas del romano (Sagredo 1986), a brief architectural treatise with an impressive display of classical language and the first in Europe to be written in the vernacular. At the same time, several young figures were coming to the fore, the famous eagles of the Spanish Renaissance described by Gómez-Moreno (1983), armed with indisputable classical training and leanings.

King Charles I (1516), soon elevated to Emperor Charles V (1520), was instrumental in consolidating a Romano identity associated with imperial power, and in fact some of the earliest and most important works in the new style emerged in connection with his presence or his direct instructions. His marriage in Seville in 1526 to Princess Isabella of Portugal and the royal couple's subsequent move to Granada left both cities with a legacy of major building projects. Masters like Diego de Riaño, Pedro Machuca and Diego Siloe built works such as the city hall and the main sacristy in the cathedral, in Seville, and in Granada the Palace of Charles V at the Alhambra and the new cathedral and imperial mausoleum. All of these projects began to emerge around 1527-1528 and were well under way by the 1530s.

The vault over the antesacristy in the church of Santa María in Carmona (Fig. 1), discussed in this paper, was designed and built by Diego de Riaño between 1528 and 1534, and its forms reflect the crossroads which this master negotiated during his intense but short-lived career. ${ }^{1}$ Creatively integrated in this vault are various formal elements from different ecosystems, the geometries of which evidence the need to experiment with new adaptive logics. In short, it is a compositional exercise which, in our view, must be examined in the light of that historical awareness that Panofsky wrote about and which in Riaño's case took the form of an intense personal evolution.

\footnotetext{
${ }^{1}$ On the presence of Riaño in Carmona, see: Ampliato and Rodríguez (2017: 206ff).
} 


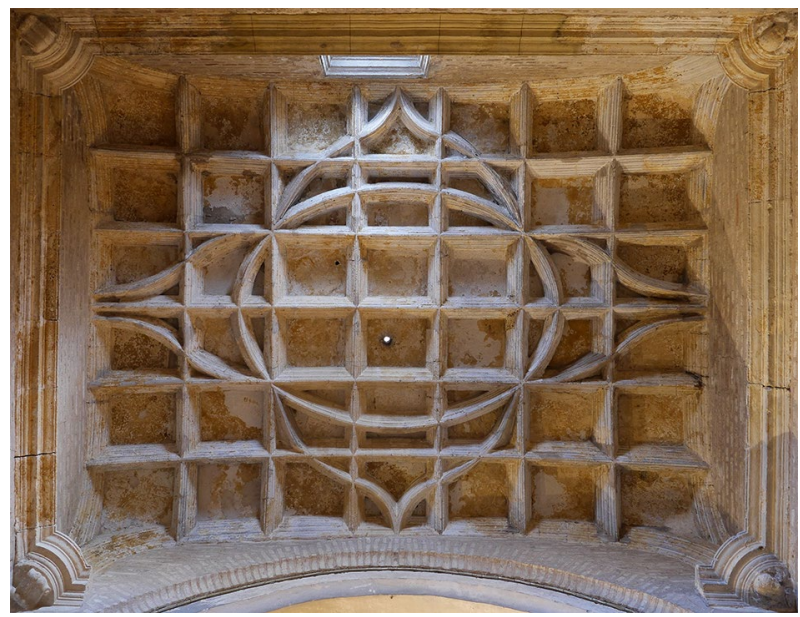

Fig. 1 Vault of the antesacristy in the church of Santa María in Carmona

\section{On the Career of Diego de Riaño}

The master Diego de Riaño was born in Cantabria, in northern Spain, at the beginning of the last decade of the fifteenth century; he died in November 1534, when he was barely 40 years old. ${ }^{2}$ The information that has come down to us about his career is scant and scattered, while the reconstruction of his personal evolution is severely hindered by the difficulties surrounding the attribution of some of his main works, a matter of near constant debate even today. In any case, the first documentary evidence that we have of the master supplies ample information. It is a dossier (Morales 1993) recording Riaño's request for a pardon from Emperor Charles V to enable him to end his exile in Portugal. Endorsed by Queen Eleanor of Portugal, the emperor's sister, the request was eventually granted. This incident prompts multiple considerations.

Firstly, the documents describe the origin of the problem: Riaño's flight to Portugal following a brawl with fatal consequences that took place in the cathedral workshop in Seville in 1517. This enables us to place the master-probably during his formative period -in the orbit of Juan Gil de Hontañón, who was in charge of the works at the cathedral during that time. Although we cannot elaborate further on this matter here, certain highly significant formal characteristics in Riaño's work would appear to confirm this relationship with a key master during the early decades of the sixteenth century in Spain (Ampliato and Rodríguez 2019).

Secondly, Riaño's exile in Lisbon between 1517 and 1522 coincided almost exactly with the crucial years in the construction of the Jerónimos monastery and

\footnotetext{
${ }^{2}$ Alfredo J. Morales has shed the most light on the life and work of Diego de Riaño. Of particular interest among his various publications on the subject is the synthesis he published in 2011 (Morales 2011).
} 
Fig. 2 Chevet of the church of Santa María in Carmona

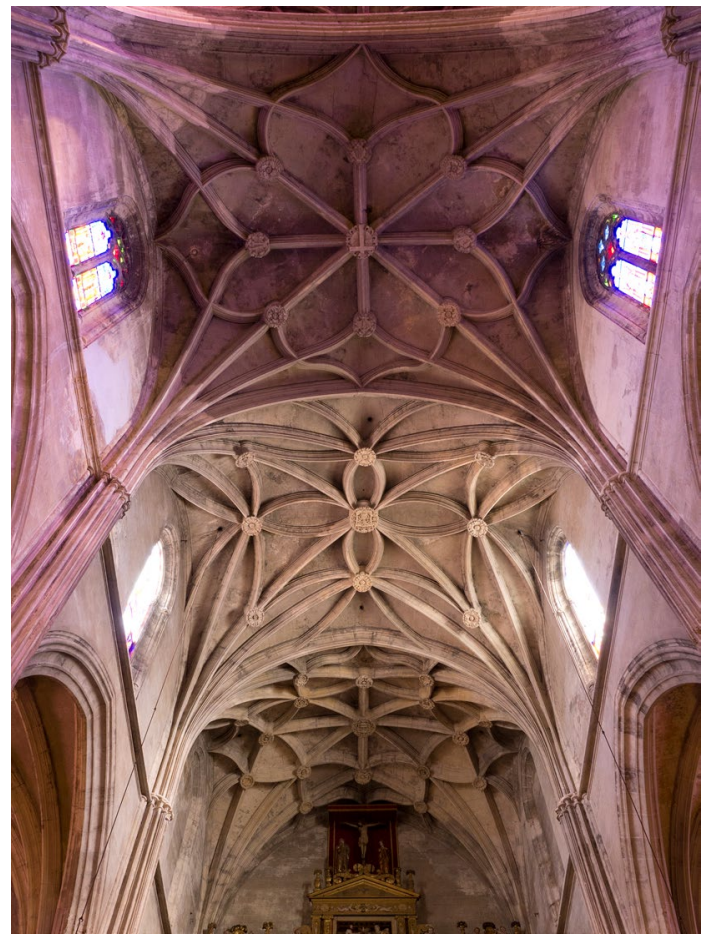

church in the parish of Belém, directed by João de Castilho (Dias 1986: 62ff.). As with Hontañón, there are also highly significant characteristics in the work of Diego de Riaño that point to an association with the Spanish-Portuguese master (Ampliato and Rodríguez 2019).

Lastly, the dossier sheds important light on another aspect about which there is no previous knowledge: the considerable esteem in which Queen Eleanor of Portugal held the master and, in general terms, his proximity to the Portuguese and Spanish crowns, which we hope future research may one day clarify further. This prestige would be confirmed, after his return to Spain, with his appointment in 1526 as master of the works for the Collegiate in Valladolid, a project deeply associated with the emperor and now unfortunately lost (Alonso 2004).

But the most interesting aspect about Riaño's career, and also the most complex, is undoubtedly the fact that his artistic production straddles two modes of operation, Gothic and Renaissance, and everything suggests that this context enabled him to make an enormous qualitative leap. The radical contrast between works like the chevet at Santa María in Carmona (Fig. 2) and the Main Sacristy in Seville Cathedral (Fig. 3a) clearly demonstrates this complexity. The general reluctance of a significant part of historians to accept this personal evolution of the master ${ }^{3}$ goes some way to explaining why the authorship of the second of these works, which

3 On these opinions, see Rodríguez and Ampliato (2019). 

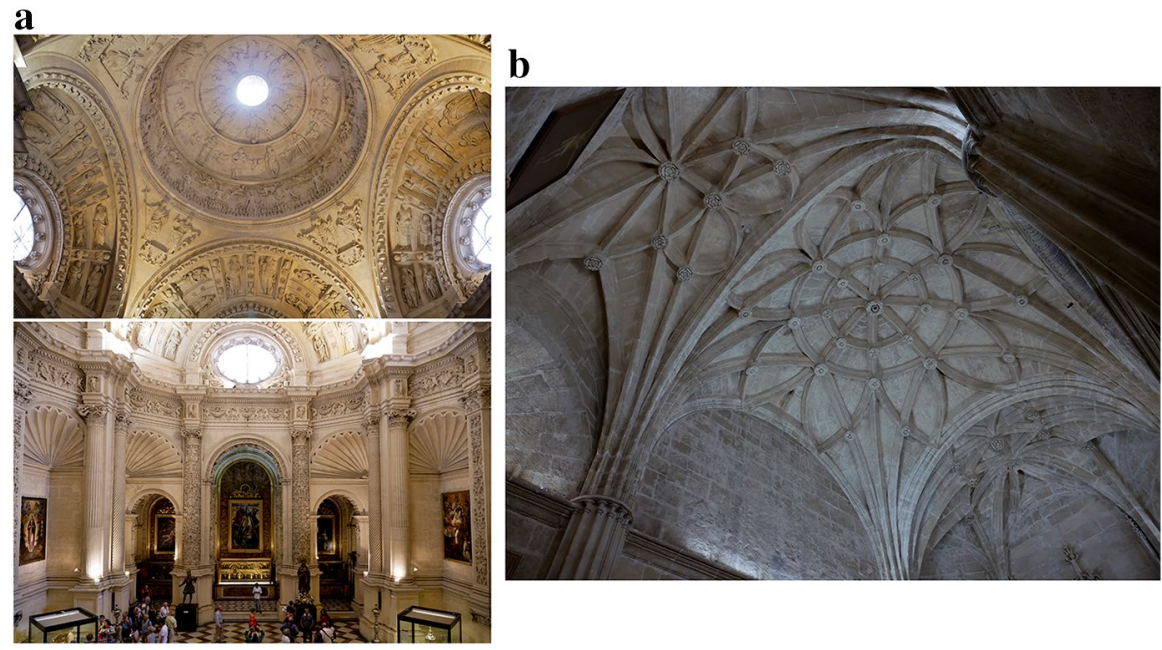

Fig. 3 Main sacristy (a) and sacristy of the Chalices (b) in Seville Cathedral

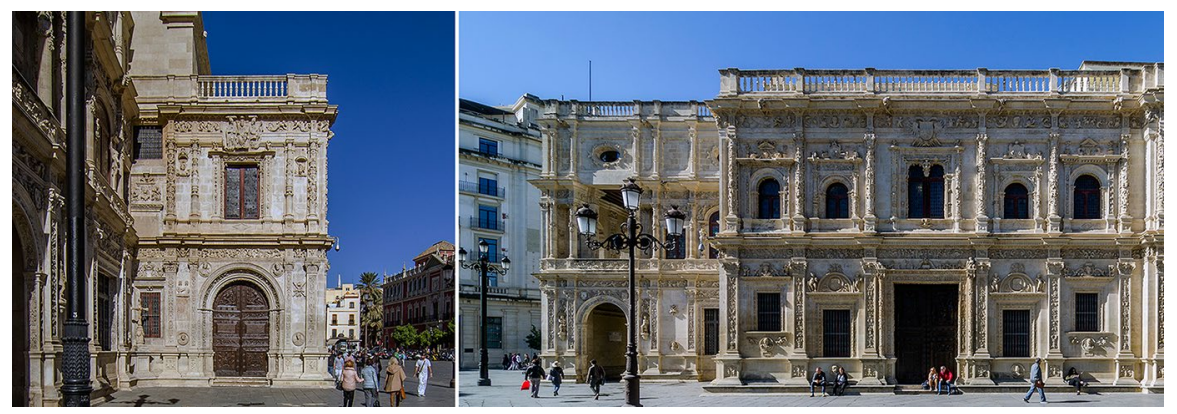

Fig. 4 South and East facades of Seville's city hall

the master could not complete, has been particularly contested, although it must be noted that nowadays it has been definitively confirmed. ${ }^{4}$ Other works by the master, with a clear tendency towards classical forms, provide further evidence of the consistency of his personal evolution. This is the case, for example, of the church of La Asunción in Aracena, barely begun by Riaño, of the Collegiate portal in Osuna, from 1533, and the facade of Seville's city hall, begun in 1527 (Fig. 4).

\footnotetext{
${ }^{4}$ In fact, it was confirmed by the solid documentary analysis presented by Aflredo Morales in 1984 (Morales 1984), which has subsequently been reinforced by recent contributions on the construction process (Rodríguez and Ampliato 2019).
} 

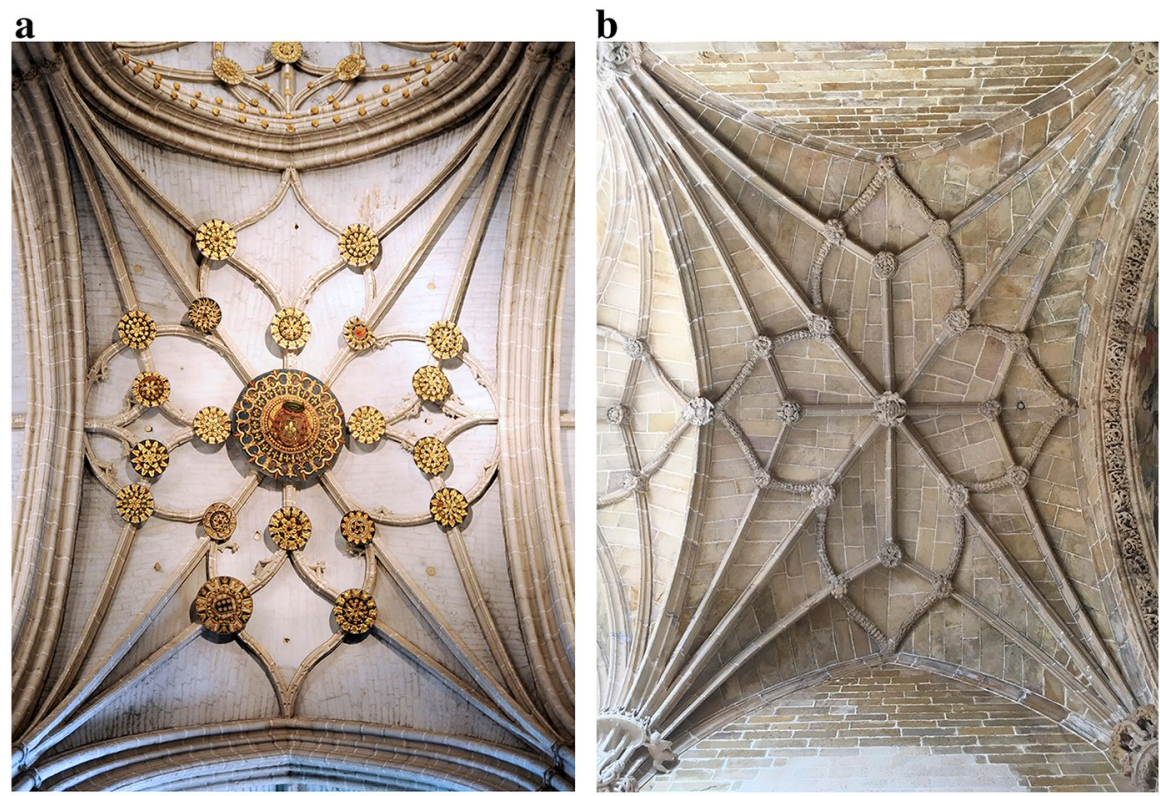

Fig. 5 Central vault of the crossing in Palencia Cathedral (a) and vault of the nave of the Convento de Cristo in Tomar (b)

\section{Formal Elements in the Vault Over the Antesacristy in Carmona}

The antesacristy in Carmona is one of a group of spaces situated in the south-east corner of the church, which also includes the sacristy and the chapel of San José and San Bartolomé. In all likelihood, the group was designed as a single entity; this is evidenced by the uniformity of the plan, the maintenance of the proportions and the systematisation of the arches that open onto the nave and aisles (Fig. 11). ${ }^{5}$ The antesacristy vault (Fig. 1) basically comprises three formal elements which may be analysed separately: a quatrefoil of warped ribs, a grid of orthogonal lines and a large central oval.

The first formal element-the warped quatrefoil—represents the essence of the final stage of evolution in Late Gothic vaults on the Iberian Peninsula. As opposed to traditional ribs (transverse, tiercerons and liernes), warped ribs add a curvature to the horizontal plane of the design which generates a slightly twisted surface. Warped ribs started appearing in Spanish vaults in the latter decades of the fifteenth century, with Juan Guas and other masters, and the form was quickly perfected. The insertion

\footnotetext{
5 Apart from Riaño's general intervention as master builder of the work in Carmona, one of the rare specific pieces of information about this section of the church is the installation of the grille for the chapel of San José and San Bartolomé in 1538. Other documents mention works in the sacristy in 1540, undoubtedly associated with the construction of a second storey. In both cases, the data trace a timeline that is consistent with the attribution to Riaño (Ampliato and Rodríguez 2017: $173 \mathrm{ff}$.).
} 


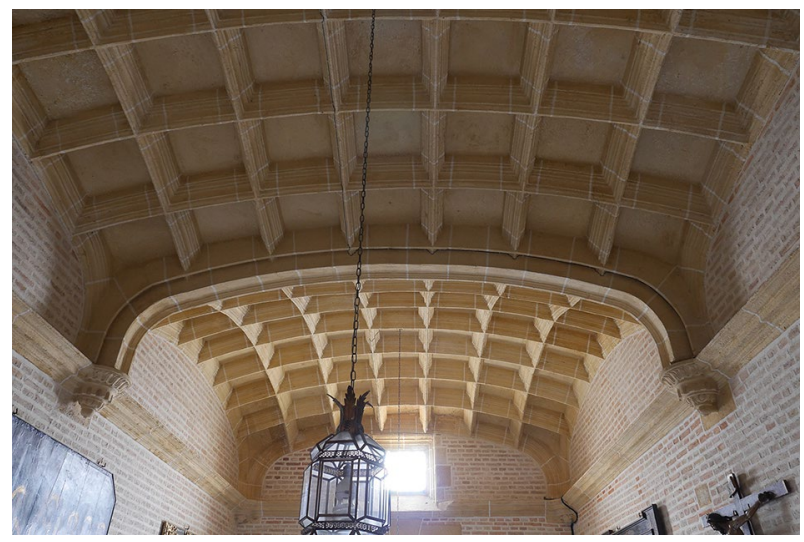

Fig. 6 Vaults of the sacristy in the church of Santa María in Carmona

of a quatrefoil of warped ogee ribs in a tierceron vault was conceived by Simón de Colonia for the central vault over the crossing in Palencia Cathedral (Fig. 5a) and the design soon became a recurring motif for a variety of authors (Gómez Martínez 1998: 93-94). Of those whom we know to have been associated with Riaño, both Juan Gil de Hontañón and João de Castilho used Colonia's model repeatedly. Particularly interesting is the fact that in the nave of the church at the Convento de Cristo in Tomar (Dias 1986: 59), João de Castillo gave the warped ribs the form of a braid, differentiating these ribs figuratively from the rest of the vault, perhaps anticipating their subsequent consideration as independent elements (Fig. 5b). Diego de Riaño himself also used the Gothic model with Simon de Colonia's warped quatrefoil in the nave and aisles of Santa María de Carmona (Fig. 2, top).

The second formal element - the grid of orthogonal ribs-is associated with a compact, unitary volume and a configuration that constituted a type of hallmark in Riaño's work (Palacios and Bravo 2013: 82-83). With its proximity to the Romano style, the grid of ribs introduced a new appearance. ${ }^{6}$ In Carmona we find the perfect model for this vault in the two modules over the sacristy to which the space in question leads (Fig. 6). Practically at the same time as Riaño, the Burgos master Diego Siloe was using vaults with grids of ribs in the atrium at Santa María del Campo, in Burgos, and in the chevet at San Jerónimo in Granada, both circa $1527-1528 .^{7}$ However, the volume of Siloe's vaults is cylindrical, closer to the Italian models which he may have seen first-hand. By contrast, in Riaño's work the motif is adapted to a pseudospherical volume, obtained by translating the ribs in both directions, with the guide of the side $\operatorname{arches}^{8}$ We will come back to this matter below.

\footnotetext{
6 According to Javier Gómez Martínez, this may stem from the French influence since numerous sculptors from France worked in Spain (Gómez Martínez 1998: 116).

7 On the work in Burgos, see Zalama (1990), and on San Jerónimo, Carrasco (2007: 408ff).

8 At a much later date, ca. 1585, Alonso de Vandelvira referred in his treatise Libro de trazas de cortes de piedras to this type of vault (fol. 99r), which by then had adopted a perfectly spherical geometry, as in his 'chapel extended by ribbed vaults'; see Barbé-Coquelin de Lisle (1977: 99).
} 

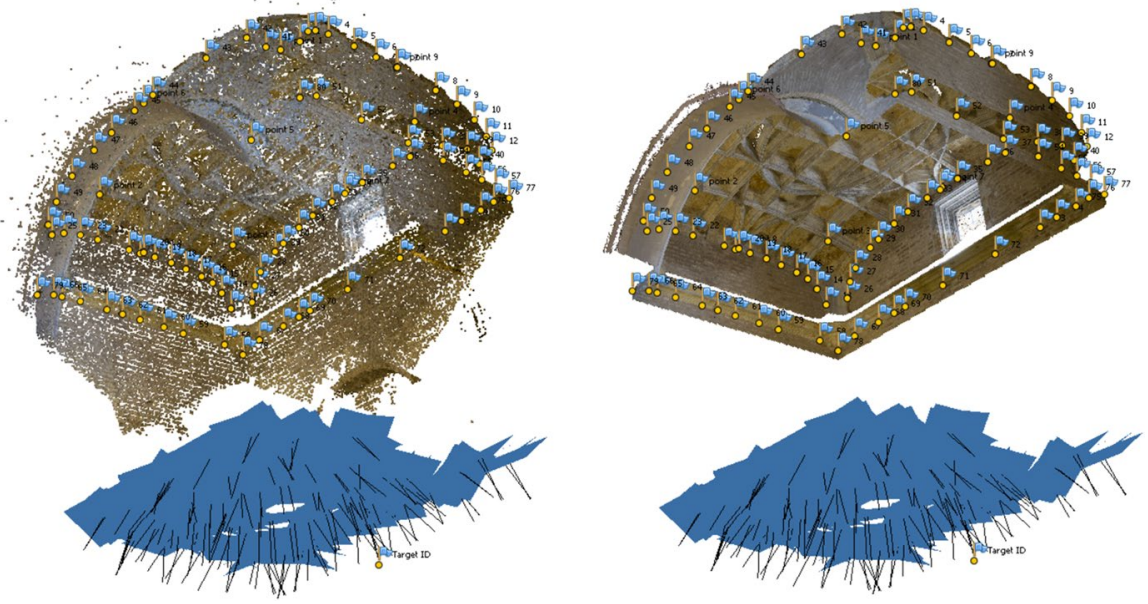

Fig. 7 Spare-cloud and dense-cloud (photographs + points) from Agisoft Photoscan

The third formal element - the oval—is the centrepiece of the composition. Since its formal characteristics are inseparable from its geometric conditions, we will address both aspects in our analysis of the design.

Lastly, we must insist on the importance of the fact that all three elements are superimposed and interlaced. As we have seen, the antesacristy in Carmona is a small passageway between spaces that belong to two separate, consecutive formal universes: the Gothic aisles in the church chevet (Fig. 2) and the evocation of the Romano style in the sacristy vaults (Fig. 6). This intermediate position of the antesacristy may well have constituted a motivation to experiment with the unique configuration of its vault.

\section{Data Collection, Modelling and Methodological Approach of the Analysis}

The first data were collected by using a total station to survey the cornices and all the side arches and ribs in the vault. At the same time, data from more than one hundred photographs were captured photogrammetically and then processed with Agisoft PhotoScan software. The result was a multi-scale and object-oriented highresolution model, with a definition threshold of less than two centimetres (Fig. 7). This precision enabled us to assess whether there were any geometric deformations stemming from the construction process or possible subsequent events, and we concluded that these deformations are minimal. Since we also mapped the adjacent spaces, we were able to complete the floor plans and sections describing the antesacristy and immediate area around it (Figs. 8, 11), a graphic result which we naturally developed while conducting the geometric analysis explained below.

The resulting 3D model was imported into the Rhinoceros program to obtain an extensive set of longitudinal and cross sections, one for each of the ribs in the 

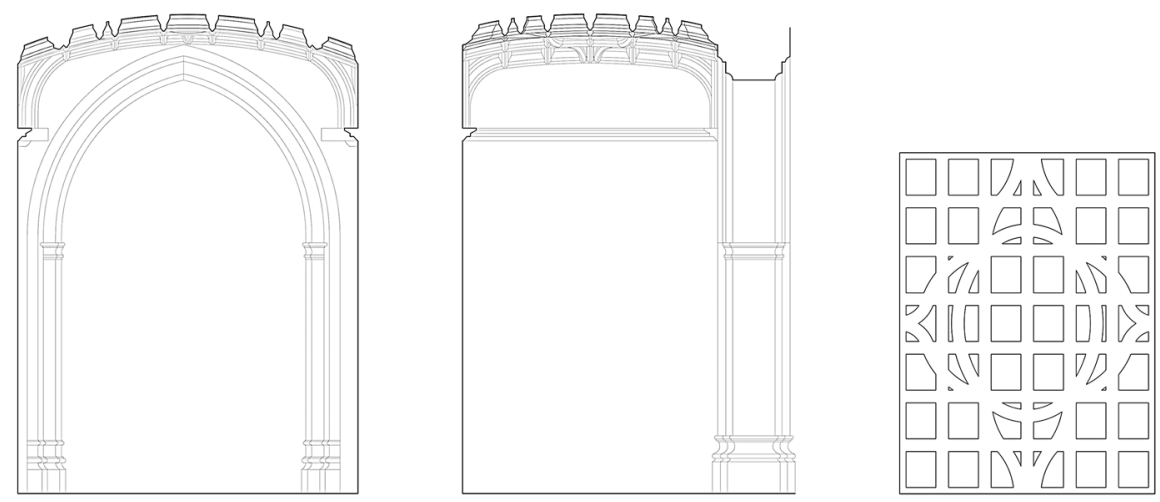

Fig. 8 Final drawings: elevations and plan from Autodesk AutoCAD
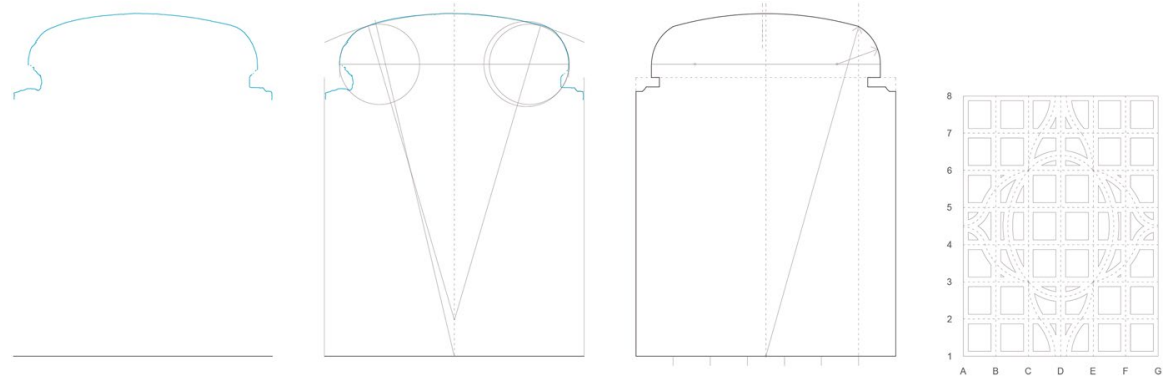

Fig. 9 Example of a raw section; section A, in blue from the photogrammetric model and drawing process to achieve the original design (colour figure online). The same procedure was used with the other sections indicated in the plan

vault and the side arches. We used Autodesk AutoCAD to find the most accurate geometric profile for each case, including the combination of arcs found in basket-handle arches (Fig. 9). Having reduced the grid of ribs to a line diagram, we were able to establish a system of local coordinates to identify the different pieces.

Our methodological approach was founded on the need to organise the successive geometric designs with a general logic which we hoped would reflect the actual design and construction of the vault as closely as possible. Consequently, the organisation explained below is determined by this aim and attempts to generate a narrative that also makes it possible to identify all the voluntary, unconditioned decisions that may have been present in each step of the process. 


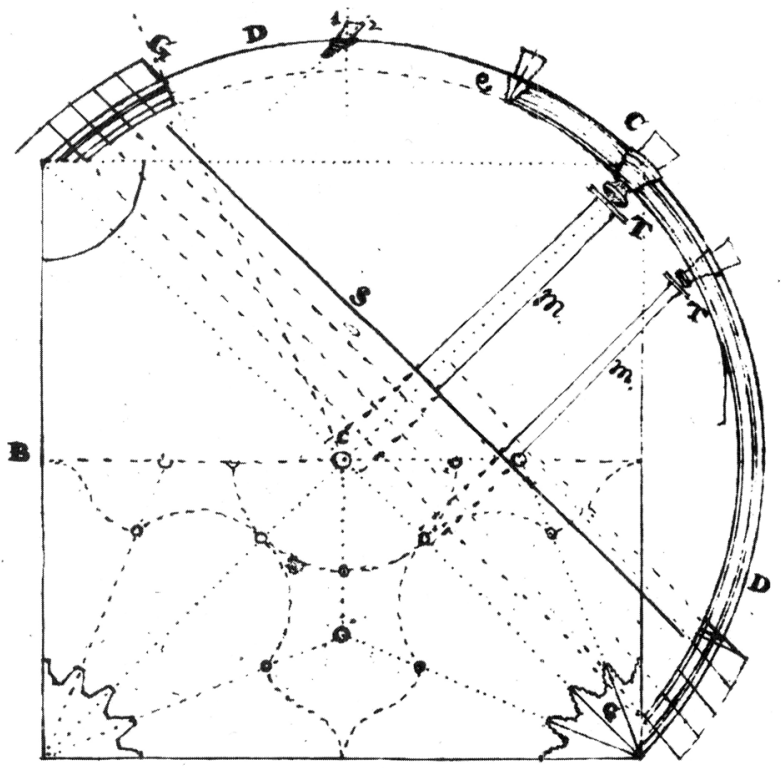

Fig. 10 Construction and assembly of a vault according to Rodrigo Gil de Hontañón (García 1681: illustration 25r)

\section{Analysis of the Geometric Design of the Ribs}

In Gothic praxis, the geometric design of a vault is performed on a horizontal plane, using a plumb to determine all the three-dimensional elements. During the construction phase, the proliferation of props and formwork represents a type of operational translation of this geometric strategy, as certain contemporary drawings clearly show (Fig. 10).

The antesacristy has a rectangular plan with a ratio of 4:3 (a sesquitertian). The short side has a whole-number measurement of 16 Castilian feet, while the long side is obtained from the latter through an operation of calculation, resulting in a non-integer (Fig. 11). Due to this precise measure, we posit that the short side was set up first. The base geometric grid for the entire composition is traced on this rectangle, halving the short side into six parts but dividing the long side into seven parts (Fig. 12a). These sub-divisions of the sides undoubtedly correspond to an initial unconditioned decision made by the master. In fact, if the long side had been also halved, the resulting cells would have been perfect squares, although this solution appears to have been deemed unsatisfactory. In the construction, although the module does not repeat the exact proportion of the plan, it is slightly rectangular and therefore echoes its elongated nature. Likewise, the division of the long side into seven parts means that the main axis of symmetry (the access trajectory from the church) is occupied by a lane instead of a rib.

As we saw with the vaults in the adjacent sacristy (Fig. 6), a simple, uniform grid pattern of ribs appears in many of Riaño's other vaults as the single formal 


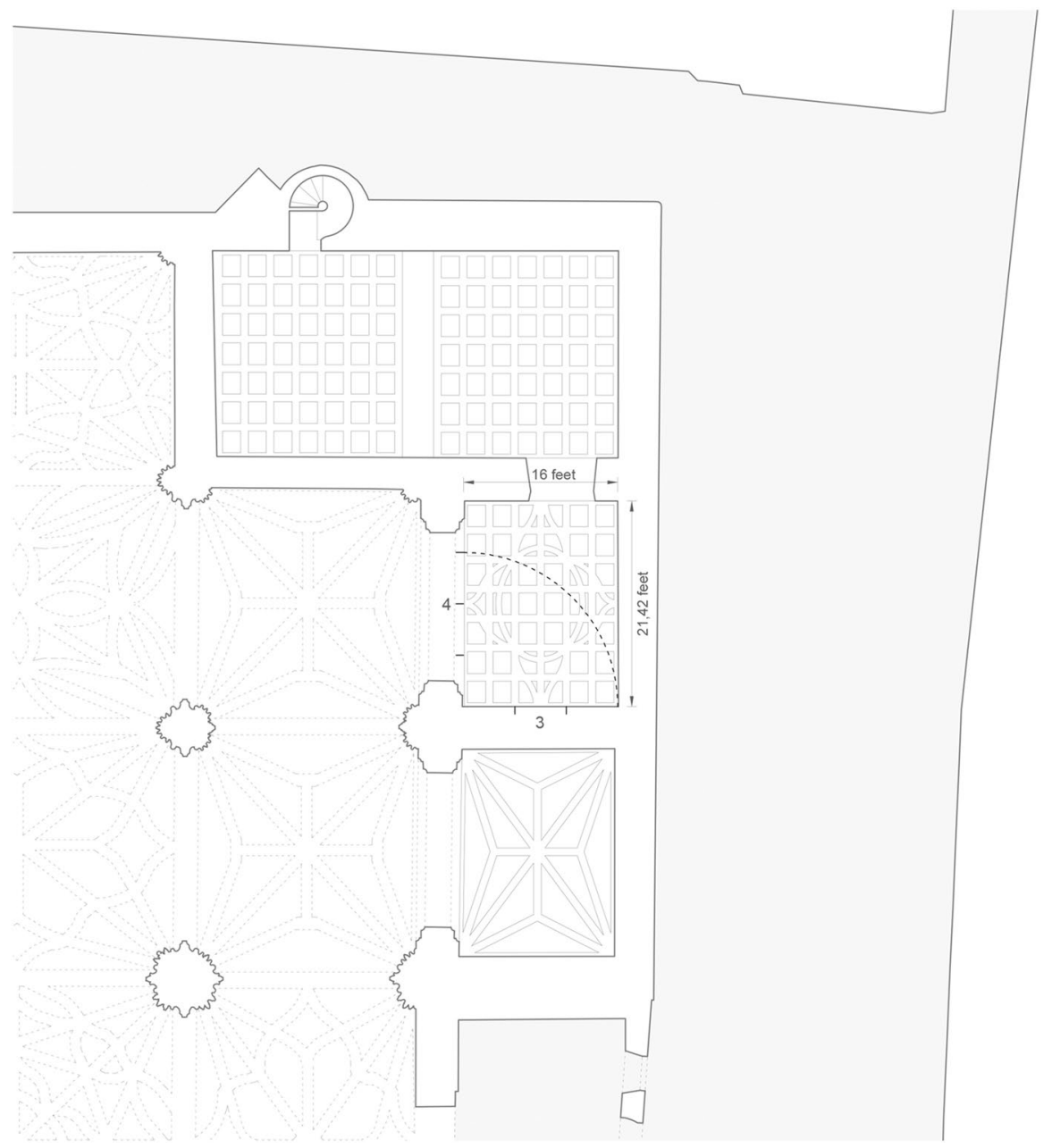

Fig. 11 Geometric proportions of the antesacristy and the separate complex of the sacristy, antesacristy and the chapel of San José and San Bartolomé

motif. Besides, in Gothic vaults it is not uncommon to find the use of an auxiliary orthogonal grid to support certain geometric operations with the ribs, although in these cases the grid never has a crucial formal significance (Palacios 2009). In the vault over the antesacristy in Carmona, the grid appears to support all the geometric operations and is clearly visible; it is both abstract and material.

In the base grid, four nodes acquire particular prominence as anchors for the three elements in the composition: grid, oval and warped ribs (Fig. 12a). These four points support the convergence of multiple ribs and are the most complex pieces to carve in stone.

The oval that dominates the composition is traced from these same four points. Its design stems from the sub-division into two parts of the rectangle which the 


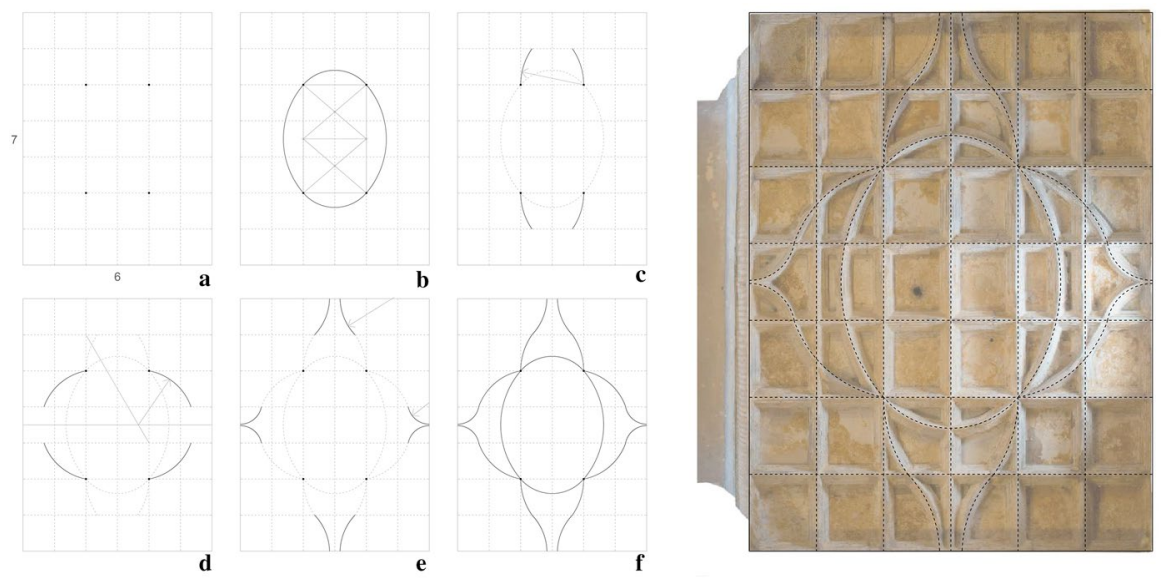

Fig. 12 Geometric procedure to obtain the grid, oval and warped ribs

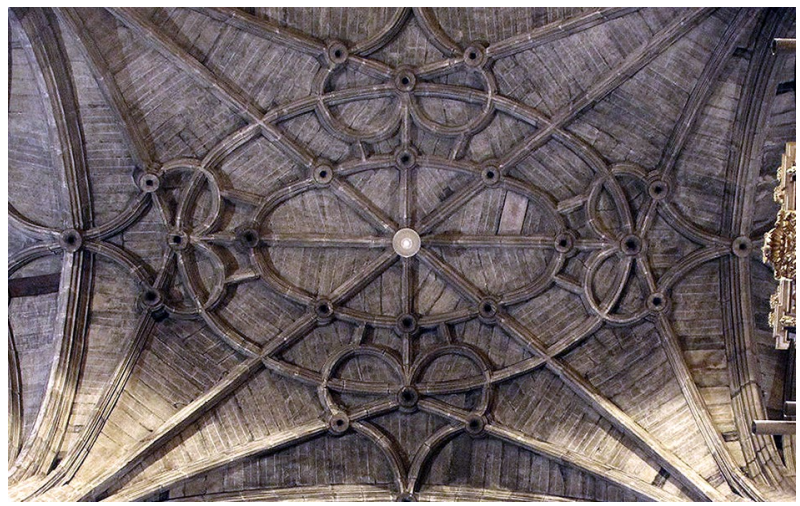

Fig. 13 Second section vault of the church of Santo Tomás in Haro. Photograph courtesy of José Carlos Palacios

four points delimit. The diagonal lines of these two smaller rectangles define the centres and radiuses of the arcs that form the oval (Fig. 12b). This oval design differs from the traditional medieval method of fixed ratios, and although we cannot rule out the possibility of it being a common practice in the workshops, the fact is that we have not been able to identify any precedents (Gentil 1996; Huerta 2007). A drawing from practically the same date as our vault, attributed to Baldassare Peruzzi and dated to before 1532, shows an oval traced free-hand from two perfect, contiguous squares (Huppert 2014: 97). His disciple Sebastiano Serlio included the same design as the terza forma ovale in his Book I, published in 1545. The designs of Peruzzi and Serlio are based on a 2:1 rectangle (a double square), while Riaño's design is more flexible as it is obtained by sub-dividing into two parts a generic rectangle, in this case conditioned by the grid. 


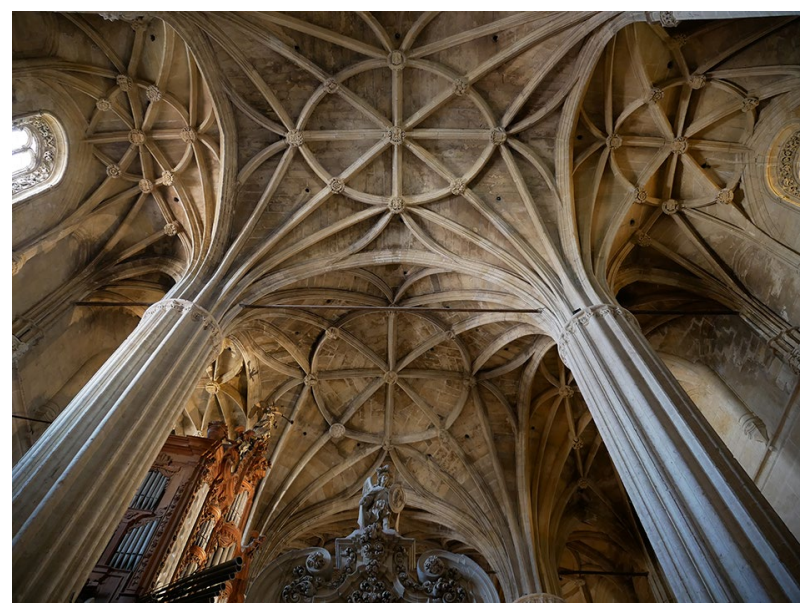

Fig. 14 First and second section vaults of the church of Santa María in Arcos de la Frontera

Regarding the insertion of ovals into Spanish Gothic vaults, we have found only one example that predates that of Carmona: the first two sections of the church of Santo Tomás in Haro, attributed to Simón de Colonia (Fig. 13), whose geometric design has yet to be analysed (Barrón 2013: 275ff.). However, in the late fifteenth century it became much more frequent to insert a circular figure into Gothic vaults, and they are found in both the square-plan and rectangular-plan types. These circles appear to have their own value as recognisable, non-deformable figures, which means that in the case of rectangular plans it is always the other ribs (tiercerons and warped ones) that fill the distance between the central circle and the rectangular perimeter (Gómez Martínez 1998: $91 \mathrm{ff}$.$) .$

In the antesacristy in Carmona, the oval figure interlocks with a grid-based geometric system that respects the proportions of the plan, which seem to be conveyed in the oval figure itself. Although this is not a literal projective transformation, it does suggest a certain parallel between the circle-oval duality and the square-rectangle duality. This sheds an interesting light on some of Riaño's works. As opposed to all of the cases discussed above, in the ribbed vaults where Riaño inserts circles they are systematically associated with a square plan, and yet when he adapts the compositional motif to a rectangular plan, he transforms the circle into an oval (or pseudo-oval, for building considerations that are irrelevant to the matter in hand), as we find in the church of Santa María in Arcos de la Frontera (Fig. 14).

But Riaño's work prompts other interesting considerations in this respect. In the Sacristy of the Chalices in Seville Cathedral (Fig. 3b) the figure of the circle is not only repeated in the main vault, which is square plan, but all the side arches and transverse ribs in the vault also present a circular geometry, generating a vault whose volume, except for small adjustments, bears a great resemblance to that of a spherical matrix. Yet Diego de Riaño designed and built this sacristy at the same time as the contiguous Main Sacristy (Fig. 3a), creating a fascinating architectural 


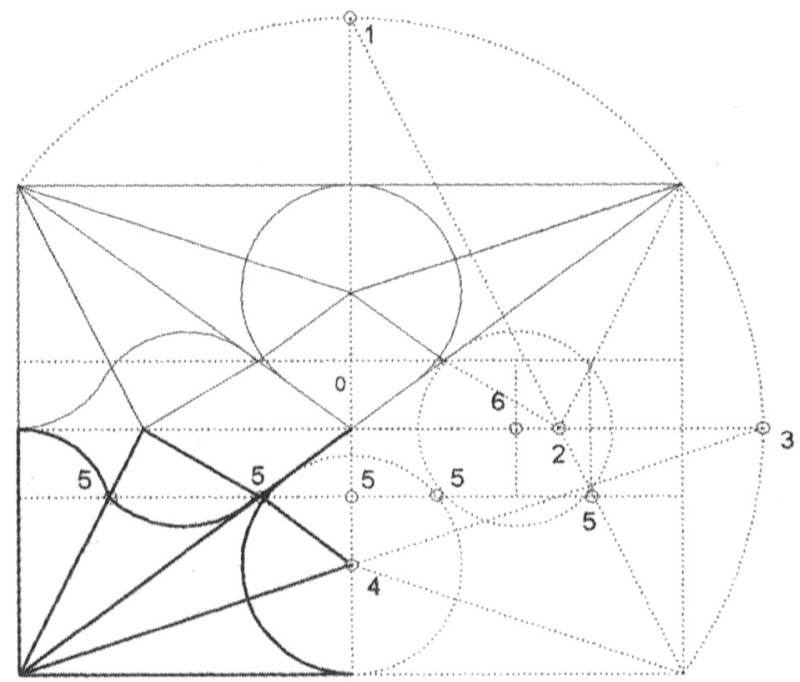

Fig. 15 Drawing of a ribbed vault starting from tiercerons located in the bisector. Image (Palacios 2009: 80), reproduced by kind permission

complex that accommodates two spaces and, we might say, two consecutive periods. In view of this chronological simultaneity, we believe that the abstract presence of the circle and the sphere in the vault over the Sacristy of the Chalices must be considered in relation to the Romano geometric structures of the adjacent Main Sacristy, a fact which, supported by all of the previous observations, lends greater significance to the use of the circle and the oval in Riaño's vaults.

Lastly, with respect to the quatrefoil of warped ogee ribs, we return to the starting point of the four central nodes in the grid. The fact that the design of the warped ribs was adapted to these nodes represents a departure from the traditional method used to insert ribs into Gothic formal compositions, which was based on specific sub-divisions (Fig. 15). In Carmona, the two largest ogee figures offer the purest geometric design. Not only do they alternately take two of the four main nodes as their centre and springing line in each case, but also, they allow the grid modulation itself to determine the length of each arc (Fig. 12c). Meanwhile, the geometric design of the two smaller ogee figures appear to be more disrupted by the rectangular ratio of the plan and base grid. Precisely because of this, it is interesting to discover, as we shall see later, that the grid also determines the intermediate geometric operations. Here we find another unconditioned decision by the master, which leads him to place the centres of the arcs on the axis of symmetry of the plan and a sub-division of one of the modules (Fig. 12d). The base grid serves as a board on which it is possible to directly establish the proportions, at any time, of any sub-division simply by choosing the correct diagonal. It is likely that after several trials and errors in search of the perfect result, the centres of these smaller arcs were situated on the axis of symmetry of the plan on a sub-division of $1 / 3$ of the module, calculated directly, and here as well the beginning and end of each arc are 

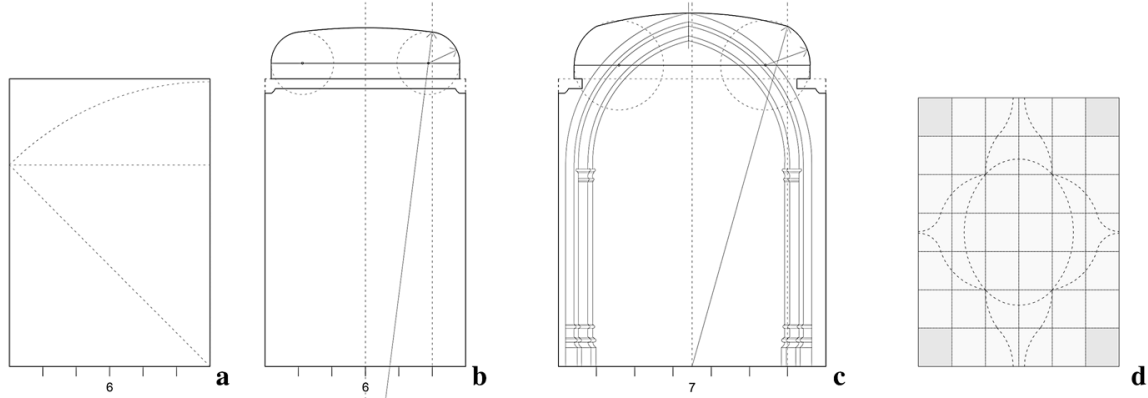

Fig. 16 Geometric procedure to obtain the elevations and vault plan with irregular modules at the corners

determined by the nodes and the grid modulation. Hence, unlike the larger ogee ribs, the two arcs that form the springing line for each pair of small ogee ribs stem from a single circle.

To complete the four ogee figures, the circles formed by the pointed ends reveal a secondary geometric design, resolved through approximation and with an imperfect tangent between the curves (Fig. 12e). The entire geometric design, as described above, almost exactly matches the actual figure of the built vault (Fig. 12f).

\section{Three-Dimensional Geometry}

On the short side of the plan, which as mentioned measured 16 Castilian feet, the ratio of the cornice height to the base is 10:7: in other words, a whole-number approximation to the square root of 2 (Fig. 16a). On this cornice line, the four side arches adopt a stilted form and the position of their centres appears to have been decided by the trial-and-error method.

The smaller side arch, of basket-handle or oval form, displays greater geometric regularity and probably stems from a tentative decision regarding the design of the central section. The length of this central section is once again exactly delimited at the ends by the sub-divisions of the plan (1/6 in this case). The smaller sections of the arch are completed by following the geometric rule that guarantees the tangent by the superimposition of the two adjacent radiuses (Fig. 16b).

By contrast, the larger side arch presents significant irregularities (Fig. 16c). The central section is higher, probably to accommodate the entrance connecting it to the church. As in the previous case, the length of this central section corresponds strictly to a sub-division of the grid (here, 1/7). However, the end sections do not follow the geometric rule of the tangent, generating a discontinuity in the design that is barely noticeable at first sight. The nature of these irregularities is unclear, but their origin is necessarily empirical.

The adjustment of the length of the central sections of the four side arches serves a very clear purpose: to concentrate all the geometric singularities for the cutting of the stone in the four modules at the corners (Fig. 16d). This is a common practice in 
a

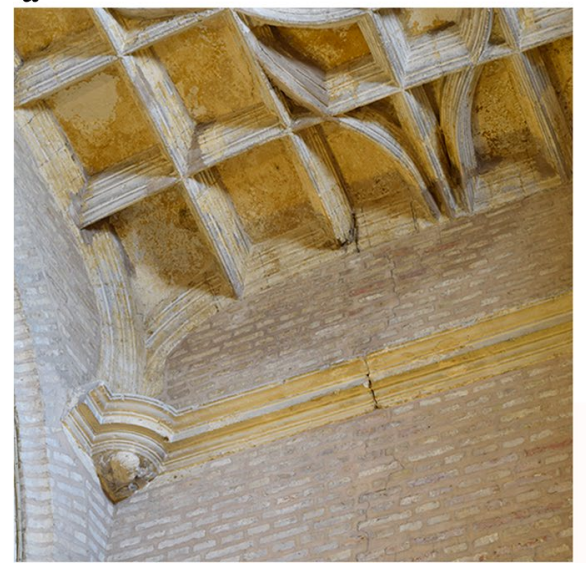

b

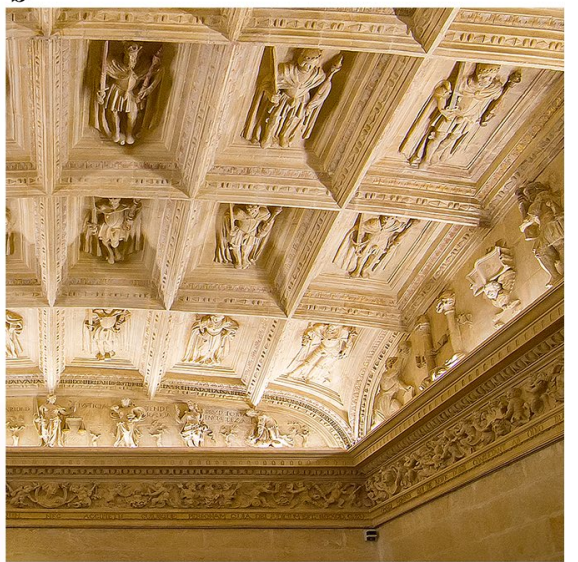

Fig. 17 Irregular corner module at the antesacristy (a); the same at the ground-floor chapter room in Seville's city hall (b)
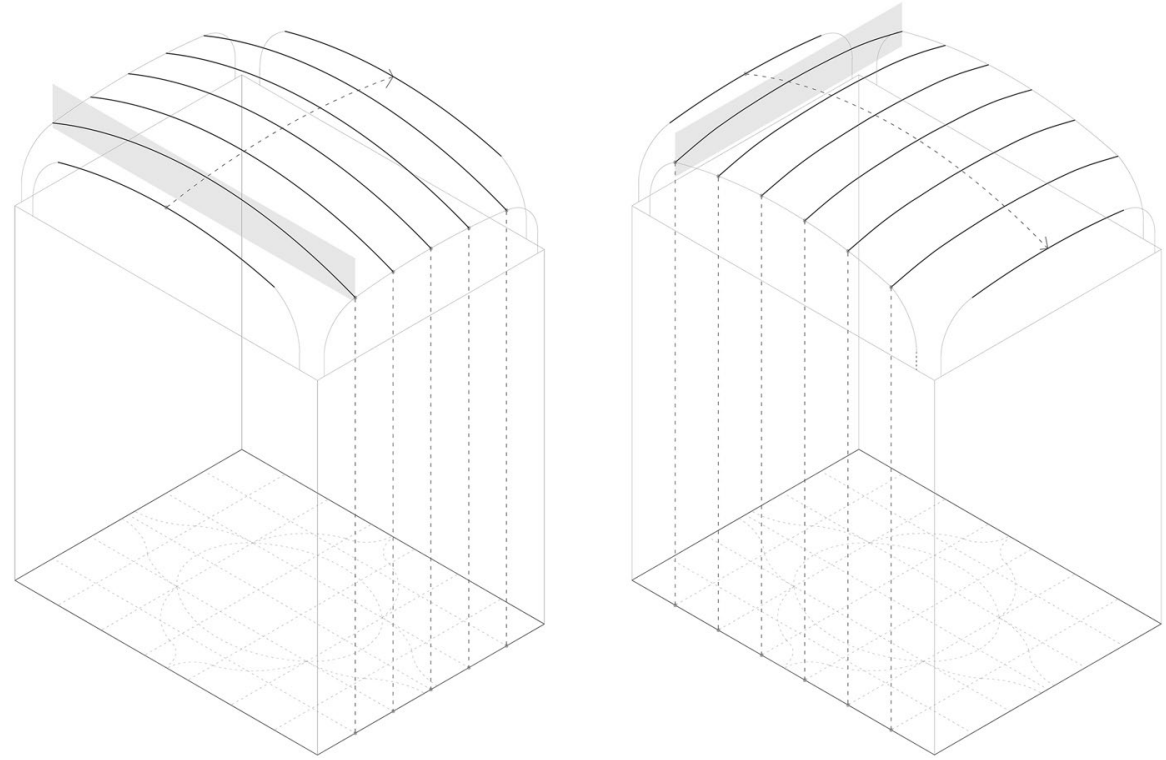

Fig. 18 Axonometries of the antesacristy and the translation of all the ribs from the side arches

Riaño's vaults, as we see for example in the one that covers the ground-floor chapter room in Seville's city hall (Fig. 17).

Having designed the side arches, what remained was the development of all the ribs in the vault. The drawing is completed by taking the central section of the wall arch, in each direction, and repeating it through translation with the guide of the perpendicular arch. This translation maintains the verticality of the plan containing 
the arch at all times, and a rib is gradually defined for each of the sub-divisions of the plan (Fig. 18). The alteration introduced in the larger side arch to accommodate the pre-existing elements of the entrance prevents the use of the same arch for the vault ribs in both directions.

\section{Conclusions}

Diego de Riaño designed an innovative vault for the antesacristy of Santa María in Carmona, a vault with its own personality but clearly conditioned by the formal diversity of the area immediately adjacent. The vault, in the last chapel on the Epistle side, is located in an area of the church that receives little foot traffic but is nevertheless strategically positioned as the passageway between the Gothic aisles and the Romano-style sacristy. The position of the antesacristy as a side chapel, the proportion of the walls and plan, and the shape of the entrance are all in keeping with the overall church complex. However, in view of its function as a space of connection and the Romano-style grid of the vault, it is an integral part of a separate complex containing the sacristy itself. All of these conditions appear to have affected the configuration of the vault, conceived as a superimposition or articulation of successive styles, Gothic and Renaissance.

The design of the vault is based on a grid plan that supports all of the other elements. Conditioned by this grid, the geometric design of the warped ribs constitutes a departure from the medieval references, while the design of the oval contains several innovative aspects. The warped ribs and oval are interrelated within the Romano grid, making the composition of this vault highly unique. The approach adopted in this unusual vault may have presented certain problems for its construction, but these very conditions have proved to be essential for gaining a true comprehension of the vault.

Overall, the antesacristy in Carmona is a product of its context and time: Spain in the third decade of the sixteenth century, immersed in major political, social and cultural changes. During those years, Diego de Riaño was active in several places in the Kingdom of Seville and was able to test various geometric and decorative solutions for this ribbed vault prolonged by translation, to the extent that it became something of a hallmark of his work. The unique, eclectic formalism of the vault of the antesacristy in Carmona undoubtedly occupies a special place in this period of fertile experimentation which has yet to be investigated more fully.

Acknowledgements All drawings and photographs presented in this article are by the authors, unless the opposite is specifically indicated.

Funding The research was funded by the R\&D project HAR 2016-76371-P, Government of Spain, 2017-2019. 


\section{References}

Alonso Ruíz, Begoña. 2004. Diego de Riaño y los maestros de la colegiata de Valladolid. De arte: revista de historia del arte 3: 39-54.

Ampliato Briones, Antonio Luis and Rodríguez Estévez, Juan Clemente. 2017. La obra nueva de Santa María. Crónica de una construcción. In: La obra gótica de Santa María de Carmona. Arquitectura y ciudad en la transición a la edad moderna, 173-212. Seville: Editorial Universidad de Sevilla and Ayuntamiento de Carmona.

Ampliato Briones, Antonio Luis and Rodríguez Estévez, Juan Clemente. 2019. Sobre la discutida identidad arquitectónica de Diego de Riaño en la transición del Gótico al Renacimiento en España. In: Actas del III Congreso Internacional Hispanoamericano de Historia de la Construcción 1: 49-61. Madrid: U.N. Autónoma de México, U. Politécnica de Madrid, Instituto Juan de Herrera.

Barbé-Coquelin de Lisle, Geneviève. 1977. Tratado de Arquitectura de Alonso de Vandelvira. Albacete: Caja de Ahorros.

Barrón García, Aurelio. 2013. La Iglesia de Santo Tomás de Haro (La Rioja). Construcciones y reconstrucciones en los siglos XV y XVI. Artigrama: Revista del Departamento de Historia del Arte de la Universidad de Zaragoza 28: 273-284.

Carrasco De Jaime, Daniel José. 2007. Documentos para una nueva aproximación al proyecto de la capilla mayor del Real Monasterio de San Jerónimo Extramuros de Granada. Cuadernos de arte e iconografía 16(32): 385-422.

Dias, Pedro. 1986. João de Castilho e o desenvolvimento da arquitectura manuelina. In: História da Arte em Portugal. Lisbon: Publicaçoes Alfa.

García, Simón. 1681. Compendio de Architectura y simetría de los templos. MSS/8884, Biblioteca Nacional de España, Madrid.

Gentil Baldrich, José María. 1996. La traza oval y la sala capitular de la Catedral de Sevilla: una aproximación geométrica. In: Quatro edificios sevillanos: metodología para su análisis, J. A. Ruiz de la Rosa, et al. eds., 73-147. Seville: Colegio de Arquitectos.

Gómez Martínez, Javier. 1998. El gótico español de la edad moderna: bóvedas de crucería. Valladolid: Secretariado de Publicaciones e Intercambio Científico, Universidad Valladolid.

Gómez-Moreno, Manuel. 1983. Las águilas el Renacimiento español (1941). Madrid: Xarait.

Huerta, Santiago. 2007. Oval Domes: History, Geometry and Mechanics. Nexus Network Journal 9: 211-248.

Huppert, Ann Claire. 2014. Practical Mathematics in the Drawings of Baldassarre Peruzzi and Antonio da Sangallo the Younger. In: Geometrical Objects: Architecture and the Mathematical Sciences 1400-1800, Anthony Gerbino, ed., 79-106. Springer Professional.

Marías, Fernando. 1989. El largo Siglo XVI: los usos artísticos del Renacimiento español. Madrid: Taurus.

Morales, Alfredo José. 1984. La Sacristía Mayor de la Catedral de Sevilla. Seville: Diputación de Sevilla.

Morales, Alfredo José. 1993. Diego de Riaño en Lisboa. Archivo Español de Arte 66(264): 404-407.

Morales, Alfredo José. 2011. Diego de Riaño. In: El ciclo humanista. Arquitectos I (Proyecto Andalucía. Artistas andaluces y artífices del arte andaluz, Vol. XXV). Seville: Publicaciones Comunitarias.

Palacios, José Carlos. 2009. La cantería medieval: la construcción de la bóveda gótica española. Madrid: Munilla-Lería.

Palacios, José Carlos. and Bravo, Sandra Cynthia. 2013. Diseño y construcción de las bóvedas por cruceros en España durante el siglo XVI. Informes de la Construcción 65(Extra-2): 81-94.

Panofsky, Erwin. 1960. Renaissance and Renascences in Western Art. Stockholm, Almquist \& Wiksells. Spanish trans. Renacimiento y renacimientos en el arte occidental. Madrid: Alianza Universidad, 1985.

Rodríguez Estévez, Juan Clemente and Antonio Luis Ampliato Briones. 2019. Diego de Riaño y la Sacristía Mayor de la Catedral de Sevilla: nuevas consideraciones sobre su autoría. Laboratorio de Arte 31 (in press).

Sagredo, Diego de. 1986. Medidas del romano (1526). Madrid: Dirección General de Bellas Artes y Archivos.

Zalama Rodríguez, Miguel Ángel. 1990. Diego de Siloé y la torre de Santa María del Campo (Burgos). Boletín del seminario de Estudios de Arte y Arqueología (BSAA) 56: 404-414. 
Publisher's Note Springer Nature remains neutral with regard to jurisdictional claims in published maps and institutional affiliations.

Antonio Ampliato (Seville, 1958), doctor of architecture, professor of architectural graphic expression at the University of Seville. Since publishing his first book, Muro, orden y espacio en la arquitectura del Renacimiento andaluz [Wall, Order and Space in the Architecture of the Andalusian Renaissance] (1996, based on his doctoral thesis presented in 1991), he has conducted extensive research into the architecture of the Renaissance and Late Gothic in Andalusia. Adopting a hermeneutic approach, he has studied the idea of architectural space in the work of a number of sixteenth-century architects, such as Diego Siloe, Diego de Riaño, Andrés de Vandelvira and Hernán Ruiz II. He was the lead researcher of the R\&D project "Sevillian Cathedral Gothic: Architecture and City in the Areas of Influence of the Cathedral of Seville" (HAR2012-35152, Government of Spain, 2013-2016). Together with the doctor of history Juan Clemente Rodríguez-Estévez, he is currently the co-leader of the R\&D project: "Diego de Riaño, Diego Siloe and the Transition from Gothic to Renaissance in Spain (HAR 2016-76371-P, Government of Spain, 2017-2019).

Eduardo Acosta (Seville, 1990), architect and master in repair and renovation of buildings (University of Seville). He has previously collaborated in the R\&D project HAR2012-35152 "Sevillian Cathedral Gothic: Architecture and City in the Areas of Influence of Seville Cathedral", funded by the Ministry of Economy and Competitiveness of the Government of Spain (2013-2016). He has carried out heritage analyses and surveys using 2D/3D scanning and photogrammetry (SfM). As a doctoral student in surveying and cultural heritage, he is currently studying the geometry and proportions in Diego de Siloe's work as a key tool for understanding the new Renaissance ideas, while applying the latest surveying techniques for heritage analysis (laser scanning, photogrammetry, etc. (2016 to present). He is member of the R\&D project HAR2016-76371-P "Diego de Riaño, Diego de Siloe and the Transition from Gothic to Renaissance in Spain/Architecture and City: Technology, Language and Spatial Conception”, funded by the Government of Spain (2016 to present). 